\title{
Uji resistensi Escherichia coli dari peternakan ayam ras petelur di Desa Rumpin Kabupaten Bogor terhadap antibiotik
}

\author{
Nursa Rima Putri ${ }^{1}$, Usamah Afiff ${ }^{2}$, , Risa Tiuria ${ }^{2}$ \\ ${ }^{1}$ Program Sarjana Fakultas Kedokteran Hewan, Institut Pertanian Bogor \\ ${ }^{2}$ Divisi Mikrobiologi Medik, Departemen Ilmu Penyakit Hewan dan Kesehatan Masyarakat Veteriner, \\ Fakultas Kedokteran Hewan, Institut Pertanian Bogor
}

\begin{abstract}
ABSTRAK: Escherichia coli merupakan flora normal yang ada di usus manusia dan hewan. Antibiotik berperan sebagai terapi terhadap infeksi E. coli. Penggunaan antibiotik secara tidak bijak dapat menimbulkan resistensi. Tujuan penelitian ini adalah mengukur tingkat resistensi $E$. coli yang diisolasi dari ayam ras petelur terhadap sefpodoksim, sefoksitin, seftizoksim, aztreonam, oksasilin, nitrofurantoin, dan sulfametoksazol-trimetoprim. Sampel uji berasal dari swab kloaka ayam ras petelur. Pengujian resistensi $E$. coli terhadap antibiotik dilakukan dengan metode difusi agar. Hasil yang diperoleh kemudian dibandingkan dengan Clinical Laboratory Standards Institute. Hasil penelitian menunjukkan bahwa 17 isolat E. coli mengalami resistensi terhadap sefpodoksim $(100.0 \%)$, sefoksitin $(58.82 \%)$, seftizoksim $(100.0 \%)$, aztreonam $(94.12 \%)$, oksasilin $(100.0 \%)$, nitrofurantoin $(58.82 \%)$, dan sulfametoksazol-trimetoprim $(82.35 \%)$.
\end{abstract}

Kata kunci:

antibiotik, Escherichia coli, layer, resistensi, uji resistensi

\section{- PENDAHULUAN}

Antibiotik merupakan obat untuk mencegah dan mengobati infeksi bakteri pada hewan dan manusia. Penggunaan antibiotik yang tidak bijak dan tidak rasional menjadi pemicu munculnya resistensi antimikroba. Resistensi antimikroba ditandai dengan munculnya bakteri yang kebal terhadap pengobatan antibiotik. Bakteri resisten pada hewan ternak dapat sampai pada manusia melalui rantai makanan, lingkungan (air, udara, dan tanah), maupun kontak langsung antara hewan dan manusia (Miles et al. 2006).

Resistensi bakteri dapat menurunkan kualitas hidup, meningkatkan kerugian materi, meningkatkan angka kematian, serta mengurangi keberhasilan program peningkatan kesehatan (WHO 2014). Kasus resistensi antibiotik terus meningkat, salah satu bakteri yang telah resisten terhadap beberapa antibiotik adalah Escherichia coli (E. coli) yang merupakan flora normal yang ada di usus besar hewan dan manusia. Menurut Noviana (2004), E. coli saat ini telah banyak mengalami resisten terhadap antibiotik golongan $\beta$-laktam, fosfomisin, dan quinolon. Ariyani et al. (2018), juga melaporkan tingkat resistensi $E$. coli yang diisolasi dari feses pada ayam layer terhadap doksisiklin sebesar 36,36\% dan siprofloksasin $14,77 \%$.

Informasi tingkat resistensi bakteri sangat penting agar penentuan kebijakan dan penanggulangan suatu penyakit menjadi efektif dan efisien. Penelitian ini bertujuan mengukur tingkat resistensi $E$. coli yang diisolasi dari kloaka ayam ras petelur di Desa Rumpin Kabupaten Bogor terhadap sefpodoksim, sefoksitin, seftizoksim, aztreonam, ksasilin, nitrofurantoin, dan sulfametoksazol-trimetoprim.

\section{- MATERI DAN METODE}

Bahan: Sampel swab kloaka ayam ras petelur (30 sampel), media isolasi dan identifikasi, cakram antibiotik nitrofurantoin $300 \mu \mathrm{g}$, sefpodoksim $10 \mu \mathrm{g}$, sefoksitin $30 \mu \mathrm{g}$, sulfametoksazol-trimetoprim $25 \mu \mathrm{g}$, oksasilin $5 \mu \mathrm{g}$, aztreonam $30 \mu \mathrm{g}$, dan seftizoksim $30 \mu \mathrm{g}$.

Isolasi dan Identifikasi Bakteri: Isolasi dan identifikasi bakteri sesuai dengan Markey et al. (2013).

Pengujian Kepekaan Antibiotik: Metode difusi agar cakram antibiotik menurut Kirby-Bauer.

Analisis data: Mengacu pada Clinical Laboratory Standards Institute (CLSI) 2018.

\section{- HASIL DAN PEMBAHASAN}

Identifikasi sampel swab kloaka: Identifikasi pada 30 sampel swab kloaka dilakukan dan hasil menunjukkan terdapat 17 isolat yang memiliki karakteristik yang sesuai dengan E. coli. Sampel yang positif E. coli kemudian dilanjutkan dengan pen-gujian resistensi terhadap tujuh antibiotik. Hasil uji resistensi ditentukan dengan melihat diameter zona hambat yang terbentuk pada media MuellerHinton yang mengacu pada CLSI tahun 2018. Hasil uji resistensi menunjukkan tingkat resistensi yang berbeda, dengan persentase hasil uji disajikan pada Tabel 1.

Diterima: 11-03-2020 | Direvisi: 15-04-2020 | Disetujui: 17-04-2020

(C) 2020 CC-BY-SA. Ini adalah artikel Open Access yang didistribusikan berdasarkan ketentuan dari Creative Commons Attribution ShareAlike 4.0 International License (https://creativecommons.org/licenses/by-sa/4.0/). 
Tabel 1 Hasil uji resistensi E. coli terhadap antibiotik berdasarkan jumlah dan persentase

\begin{tabular}{|c|c|c|c|c|c|c|c|}
\hline \multirow{2}{*}{ Antibiotik } & \multirow{2}{*}{$\begin{array}{l}\text { Disk } \\
(\mu g)\end{array}$} & \multirow{2}{*}{$\mathbf{S}$} & \multirow{2}{*}{ I } & \multirow{2}{*}{$\mathbf{R}$} & \multicolumn{3}{|c|}{ Persentase (\%) } \\
\hline & & & & & $\mathbf{S}$ & $\mathbf{I}$ & $\mathbf{R}$ \\
\hline Sefpodoksim & 10 & 0 & 0 & 17 & 0,00 & 0,00 & 100,00 \\
\hline Sefoksitin & 30 & 3 & 4 & 10 & 17,65 & 23,53 & 58,82 \\
\hline Seftizoksim & 30 & 0 & 0 & 17 & 0,00 & 0,00 & 100,00 \\
\hline $\begin{array}{l}\text { Sulfametoksazol } \\
\text {-trimetoprim }\end{array}$ & 25 & 1 & 2 & 14 & 5,88 & 11,77 & 82,35 \\
\hline Nitrofurantoin & 300 & 3 & 4 & 10 & 17,65 & 23,53 & 58,82 \\
\hline Aztreonam & 30 & 0 & 1 & 16 & 0,00 & 5,88 & 94,12 \\
\hline Oksasilin & 5 & 0 & 0 & 17 & 0,00 & 0,00 & 100,00 \\
\hline
\end{tabular}

Keterangan : S: sensitif; I: intermediet; R: resisten

Hasil pengujian resistensi $E$. coli terhadap antibiotik yang digunakan pada penelitian (Tabel 1) menunjukkan bahwa 17 isolat $E$. coli mengalami resisten dengan persentase $100,00 \%$ terhadap sefpodoksim, seftizoksim dan oksasilin, 58,82\% terhadap sefoksitin dan nitrofurantoin, $82,35 \%$ terhadap sulfametoksazol-trimetoprim, dan 94,12 \% terhadap aztreonam. Sifat resisten menunjukkan bahwa isolat bakteri tidak dapat dihambat oleh agen antimikrobial dengan konsentrasi yang biasa digunakan. E. coli memiliki kemampuan menghasilkan Extended Spectrum $\beta$-Laktamase (ESBL). Enzim $\beta$-laktamase yang dihasilkan bekerja menginaktivasi $\beta$-laktam, sehingga $E$. coli menjadi resisten terhadap sebagian besar antibiotik golongan $\beta$-laktam seperti sefalosporin (Ryu et al. 2012; Carattoli 2008).

Oksasilin merupakan antibiotik golongan penisilin yang aktif terhadap kelompok bakteri Gram positif (Mycek et al. 2001), sedangkan isolat yang digunakan pada penelitian ini yaitu $E$. coli yang merupakan bakteri Gram negatif. Sifat resistensi $E$. coli terhadap oksasilin merupakan resistensi alami. Resistensi alami tidak dapat diatasi dengan meningkatkan dosis antibiotik tersebut, sehingga penggunaan oksasilin sebagai obat terapi terhadap infeksi oleh $E$. coli tidak efektif. Sifat intermediet yang ditunjukkan oleh 17 isolat $E$. coli terhadap beberapa antibi-otik berarti bahwa tingkat respon agen antimikrobial terhadap isolat bakteri lebih rendah dibandingkan isolat yang sensitif (CLSI 2018).

Hasil menunjukkan bahwa 17 isolat uji telah mengalami resisten terhadap empat golongan antibiotik; sefalosporin, monobaktam, sulfonamid, dan nitrofuran. Kondisi ini disebut dengan multidrug resistant (MDR), yaitu kondisi dimana bakteri mengalami resisten terhadap minimal satu jenis antibiotik dari $\geq 3$ golongan antibiotik. MDR disebabkan karena pemakaian antibiotik yang tidak tepat dosis, tidak tepat diagnosa dan tidak tepat bakteri penyebab penyakit (Magiorakos et al. 2012).

\section{- SIMPULAN}

Hasil uji resistensi isolat E. coli menunjukkan bahwa 17 isolat $E$. coli dalam penelitian ini telah resisten ter-hadap empat golongan antibiotik; sefalosporin, mono-baktam, sulfonamid, dan nitrofuran sehingga dapat dikategorikan sebagai multidrug resistant.

\section{- INFORMASI PENULIS}

Penulis untuk Korespondensi

*UA: uafiff60@gmail.com

Divisi Mikrobiologi Medik, Departemen Ilmu Penyakit Hewan dan Kesehatan Masyarakat Veteriner, Fakultas Kedokteran Hewan, Institut Pertanian Bogor. Jl. Agatis Kampus IPB Dramaga Bogor 16680

\section{- PUSTAKA ACUAN}

Ariyani N, Nurhidayah, Istianingsih, Ambarwati, Sari RA. 2018. Doxycycline and ciprofloxacin resistance in Escherichia coli isolated from layer feces. Di dalam: Musyawarah Nasional ke III Asosiasi Farmakologi dan Farmasi Veteriner Indonesia; 2017 Okt 7-8; Surabaya, Indonesia. Surabaya

Carattoli A. 2008. Animal reservoirs for extended spectrum $\beta$-lactamase producers. Clinical Microbiology and Infection. 14(1): 117-123.

[CLSI] Clinical and Laboratory Standards Institute. 2018. Performance Standards for Antimicrobial Susceptibility Testing. 28th Ed. Wayne (US): Clinical and Laboratory Standards Institute.

Krisnaningsih MMF, Asmara W, Wibowo MH. 2005. Uji sensitivitas isolat Escherichia coli patogen pada ayam terhadap beberapa jenis antibiotik. Jurnal Sain Veteriner. 23(1):13-18.

Magiorakos AP, Srinivasan A, Carey RB, Carmeli Y, Falagas ME, Giske CG, Harbarth S, Hindler JF, Kahlmeter G, Olsson-Liljequist B, Paterson DL, Rice LB, Stelling J, Struelens MJ, Vatopoulos A, Weber JT, Monnet DL. 2012. Multidrug-resistant, extensively drug-resistant and pandrug-resistant bacteria: an international expert proposal for interim standard definitions for acquired resistance. Clinical Microbiology and Infection. 18(3):268-281.

Markey B, Leonard F, Archambault M, Cullinane A, Maguire D. 2013. Clinical Veterinary Microbiology. 2nd Ed. London (UK): Mosby Elsevier.

Miles TD, McLaughlin W, Brown PD. 2006. Antimicrobial resistance of Escherichia coli isolates from broiler chickens and humans. BMC Veterinary Research. 2(7):1-9.

Mycek MJ, Harvey RA, Champe PC. 2001. Farmakologi Ulasan Bergambar. Ed ke-2. Hartanto H, editor. Jakarta (ID): Widya Medika.

Noviana H. 2004. Pola kepekaan antibiotik Escherichia coli yang diisolasi dari berbagai spesimen klinis. Jurnal Kedokteran Trisakti. 23(4):122-126.

Ryu SH, Lee JH, Park SH, Song MO, Park SH, Jung HW, Park GY, Choi SM, Kim MS, Chae YZ, Park SG, Lee YK. 2012. Antimicrobial resistance profiles among Escherichia coli strains isolated from commercial and cooked foods. International Journal of Food Microbiology. 159(3):263-266.

[WHO] World Health Organization. 2014. Antimicrobial Resistance Global Report of Surveillance [internet]. [diunduh 2019 Maret 24]. Tersedia pada:https://apps.who.int/iris/bitstream/handle/10665/ 259744/9789241513449-eng. pdf.hlm-2. 
